\title{
A new genus and species of alvinocaridid shrimp (Crustacea: Decapoda: Caridea) from hydrothermal vents on the North Fiji and Lau Basins, south-western Pacific
}

\author{
Tomoyuki Komai $*^{\ddagger}$ and Michel Segonzac ${ }^{\dagger}$ \\ *Natural History Museum and Institute, Chiba, 955-2 Aoba-cho, Chuo-ku, Chiba 260-8682, Japan. \\ ${ }^{\dagger}$ Ifremer, Centre de Brest, DRO/EP-Centob, F-29280 Plouzané, France. \\ ${ }^{\ddagger}$ Corresponding author, e-mail: komai@chiba-muse.or.jp
}

\begin{abstract}
Nautilocaris saintlaurentae gen. nov., sp. nov., is described and illustrated from hydrothermal vents in the North Fiji Basin and Lau Basin in the south-western Pacific. This new taxon is assigned to the Alvinocarididae. It has a well-developed, dorsally dentate rostrum, carapace with pterygostomian spine present, eye broadly fused mesially, epipod-setobranch complex present above pereopods, and appendix internae on second to fourth pleopods greatly reduced. This combination of characters places it in an intermediate position between a group of species in the genus Alvinocaris with well developed, dorsally dentate rostrum, carapace with pterygostomian spine present, eyes narrowly fused mesially, epipod-setobranch complex absent and well-developed appendices internae on second to fourth pleopods, and Mirocaris fortunata with rostrum unarmed, carapace with rounded pterygostomian angle, eye broadly fused mesially, epipod-setobranch complex present above pereopods and appendices internae on second to fourth pleopods greatly reduced. The habitat of the new species is briefly described.
\end{abstract}

\section{INTRODUCTION}

Species of the family Alvinocarididae Christoffersen, 1986, recently redefined by Komai \& Segonzac (2003), are a distinct component of chemosynthetic communities occurring at hydrothermal vents or waters influenced by brine or hydrocarbon seeps. The family Alvinocarididae is represented by five genera. The type genus Alvinocaris Williams \& Chace, 1982 is widespread in the Atlantic and Pacific Oceans (Webber, 2004; Komai \& Segonzac, in press); Rimicaris Williams \& Rona, 1986 is found on the Mid-Atlantic Ridge and Kairei Field on the Indian Ocean (Shank et al., 1999; Watabe \& Hashimoto, 2002); Chorocaris Martin \& Hessler, 1990 occurs in both the Mid-Atlantic Ridge and western Pacific (Martin \& Hessler, 1990; Shank et al., 1999); Opaepele Williams \& Dobbs, 1995 is so far restricted to Hawaii in the central Pacific (Shank et al., 1999); and Mirocaris Vereshchaka, 1997 is known only from the Mid-Atlantic Ridge (Shank et al., 1999; Komai \& Segonzac, 2003).

In 1989, two diving cruises, with the aid of the submersible 'Nautile' on RV 'Nadir', were carried out on two back-arc basins in the south-western Pacific: the FrenchGerman BIOLAU cruise to the Lau Basin (Chief scientist A.-M. Alayse, Ifremer, 17 April to 10 May) and the French-Japanese STARMER II cruise to the North Fiji Basin (Chief scientists D. Desbruyères, Ifremer, and S. Ohta, Ocean Research Institute, University of Tokyo, 30 June to 19 July). Extensive sampling of the animal communities associated with hydrothermalism of these basins was made during these cruises (Figure 1). The collection of caridean shrimps, including those belonging to the families Alvinocarididae and Hippolytidae, were submitted for identification to the late M. de Saint Laurent of the Muséum National d'Histoire Naturelle, Paris. She made preliminary identifications of four species including three alvinocaridids, Chorocaris vandoverae Martin \& Hessler, 1990, Alvinocaris sp. and an undescribed species that could not be assigned to any known alvinocaridid genus; and one hippolytid Lebbeus sp. aff. washingtonianus (Rathbun, 1902). The present paper describes a new genus and new species of Alvinocarididae based on the specimens collected during those cruises. The new species appears intermediate between Mirocaris fortunata representing the monotypic Mirocaris and species of Alvinocaris. The habitat of the new shrimp is described based on submersible dive footage.

\section{MATERIALS AND METHODS}

The holotype of Nautilocaris saintlaurentae gen. nov., sp. nov. is deposited in the Muséum National d'Histoire Naturelle, Paris (MNHN, with a code of $\mathrm{Na}$ ). Paratypes are deposited in MNHN and the Natural History Museum and Institute, Chiba, Japan (CBM, with a code of $\mathrm{ZG}$ ). The size of the specimens is indicated by postorbital carapace length (CL) measured in $\mathrm{mm}$ from the level of the posterior margin of the orbit to the midpoint of the posterodorsal margin of the carapace, and/or total length (TL) measured in mm from the tip of the antennal scale to the posterior margin of the telson. The descriptive terminology follows Komai \& Segonzac (2003). 


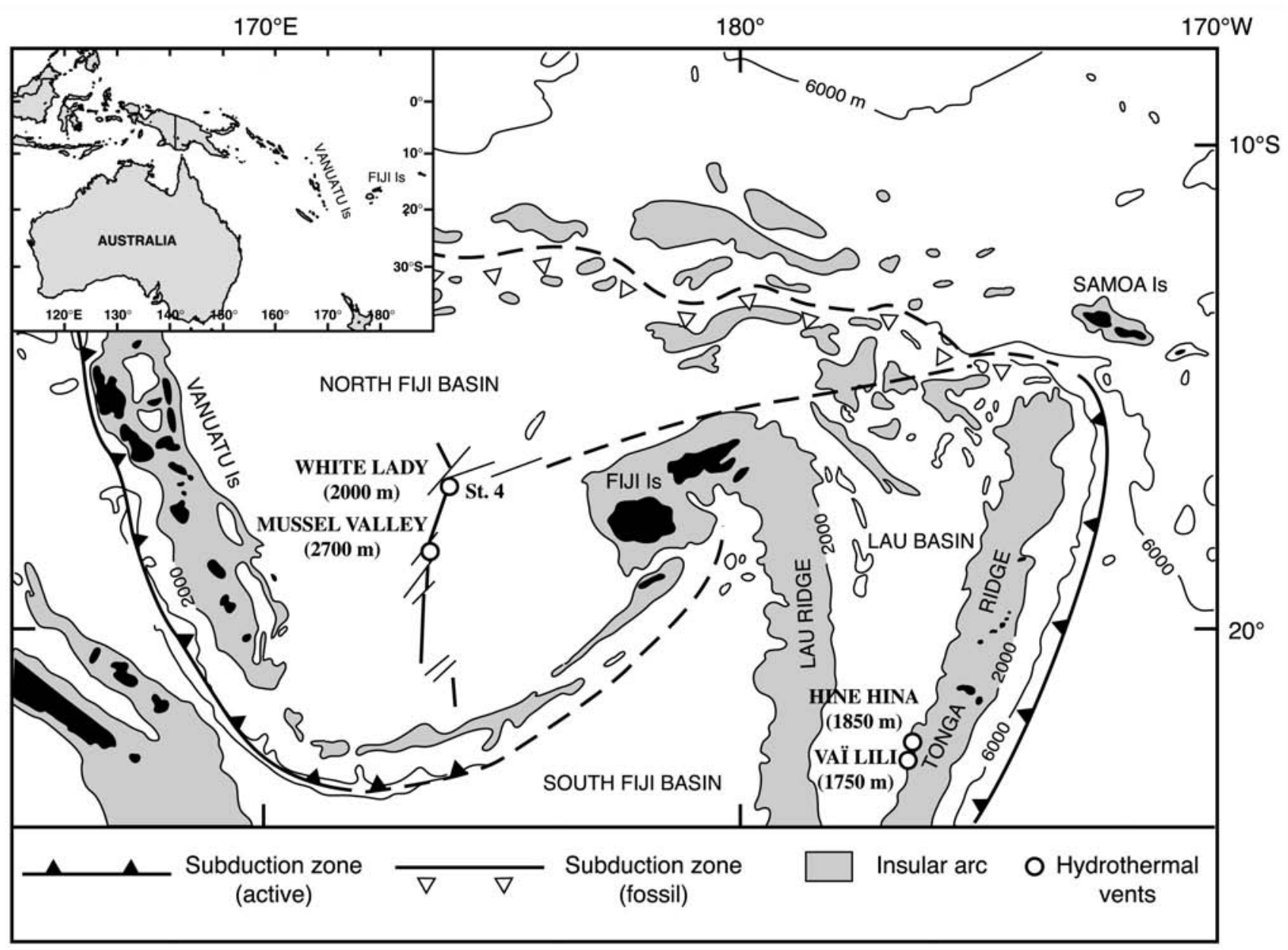

Figure 1. Geographic location of hydrothermal vents, harbouring Nautilocaris saintlaurentae gen. nov., sp. nov.

\section{SYSTEMATICS}

Order DECAPODA Latreille, 1802

Infraorder CARIDEA Dana, 1852

Superfamily BRESILIOIDEA Calman, 1896

Family ALVINOGARIDIDAE Christoffersen, 1986

Nautilocaris gen. nov.

\section{Diagnosis}

Rostrum somewhat compressed laterally, distinctly carinate and dentate dorsally, slightly falling short of or reaching distal margin of basal segment of antennular peduncle; ventral surface unarmed. Carapace somewhat compressed laterally; postrostral median carina low, blunt, restricted to anterior 0.15 of carapace; antennal tooth acuminate; pterygostomian angle weakly produced anteriorly, terminating in sharp tooth. Third to fifth abdominal pleura dentate posteroventrally. Telson with dorsolateral spines arranged in slightly sinuous row. Eyes rather large but degenerate, broadly fused mesially; anterior surface smooth; retinal pigment usually present. Antennal scale broadly oval, with distinct distolateral tooth. Third maxilliped to fourth pereopods with straplike, terminally hooked epipods, corresponding to setobranchs above first to fifth pereopods. Dactylus and fixed finger of chela of first pereopod with submarginal row of long setae on external surface adjacent to cutting edge. Meri of third to fifth pereopods unarmed; dactyli of third to fifth pereopods compressed laterally, each with single row of accessory spinules on ventral margin. Appendices internae on second to fourth pleopods greatly reduced, that on fifth pleopod well developed, bearing terminal cluster of cincinnuri.

\section{Type species}

Nautilocaris saintlaurentae sp. nov. Present designation; by monotypy.

\section{Etymology}

From the name of the French deep submersible 'Nautile', and the Greek 'karis', meaning shrimp. The gender is feminine.

\section{Remarks}

The familial assignment of the shrimp taxa exclusively associated with vent or seep environments was subject to disagreement (e.g. Williams \& Chace, 1982; Williams \& Rona, 1986; Williams, 1988; Martin \& Hessler, 1990; Holthuis, 1993; Segonzac et al., 1993; Williams \& Dobbs 1995; Vereshchaka, 1997; Shank et al., 1999). Recently, Komai \& Segonzac (2003) redefined the family Alvinocarididae and assigned to that family, the five genera Alvinocaris, Rimicaris, Chorocaris, Opaepele, and Mirocaris. Nautilocaris is immediately recognizable as one of the members of the Alvinocarididae by the apomorphic characters shared by all species of the family, such as the degenerated, mesially fused eyes and the characteristic 
antennule, mouthparts and first pereopod (Komai \& Segonzac, 2003). The new species shares the possession of epipods on the third maxilliped through fourth pereopods, the possession of submarginal rows of long setae on the outer surface of the dactylus and fixed finger of the chela of the first pereopod, and the possession of strongly reduced appendices internae on the second to fourth pleopods with Mirocaris fortunata (Martin \& Christiansen, 1995), the sole representative of the genus Mirocaris (Komai \& Segonzac, 2003). In the other genera of the Alvinocarididae, there are no epipods on the third maxilliped and pereopods; the fingers of the chela of the first pereopod lack submarginal setal rows along the cutting edges; the appendices internae on the second to fourth pleopods are better developed. The rostrum being distinctly dentate on the dorsal margin, the short but distinct postrostral ridge on the carapace, and the presence of a sharp pterygostomian spine, immediately distinguish Nautilocaris saintlaurentae from Mirocaris fortunata. The latter, presumably plesiomorphic, characters (see Komai \& Segonzac, 2003) are also found in the genus Alvinocaris. Therefore, within the family Alvinocarididae, this new species seems to occupy an intermediate position between Alvinocaris and Mirocaris fortunata. Another character differentiating Nautilocaris saintlaurentae from Mirocaris fortunata is the multi-denticulate posterolateral margins of the third to fifth abdominal pleura. In Mirocaris fortunata, those pleura are smooth and unarmed.

The discovery of this new form of alvinocaridid may raise questions concerning the phylogenetic hypothesis for the Alvinocarididae by Shank et al. (1999; as Bresiliidae). The maximum likelihood tree based on the 600 base pair (bp) nucleotide sequence of mitochondrial cytochrome $\mathrm{C}$ oxidase subunit I (COI) gene places Mirocaris fortunata (see Komai \& Segonzac, 2003) as the sister group of the other alvinocaridids (including four species of Alvinocaris, Opaepele loihi, two species of Chorocaris and Rimicaris exoculata). However, as discussed above, the present morphological data suggests that Nautilocaris sainlaurentae occupies an intermediate position between Alvinocaris and Mirocaris. The phylogenetic tree of Shank et al. (1999) is based on analysis of a short nucleotide sequence (only $600 \mathrm{bp}$ ). Future study using morphological characters and additional genes from more taxa will test the phylogenetic hypothesis by Shank et al. (1999).

\section{Nautilocaris saintlaurentae, sp. nov.}

Figures 2-6

\section{Type material}

Holotype: female CL 7.3 mm (STARMER II, dive 10, North Fiji Basin, White Lady site, $16^{\circ} 59.50^{\prime} \mathrm{S} 173^{\circ} 55.47^{\prime} \mathrm{E}$, 2000 m depth, 5 July 1989, slurp gun) [MNHN-Na 15261].

Paratypes: 3 males CL 4.8-5.6 mm, 4 females CL 5.1$7.8 \mathrm{~mm}$ (same data as holotype) [MNHN-Na 15262]; 1 male CL $4.1 \mathrm{~mm}, 2$ females CL 6.1, $6.3 \mathrm{~mm}$ (BIOLAU, BL 06, Lau Basin, Vaï-Lili site, $22^{\circ} 13^{\prime} \mathrm{S} 176^{\circ} 38^{\prime} \mathrm{W}, 1750 \mathrm{~m}$ depth, 18 May 1989, baited trap) [MNHN-Na 15263]; 2 males CL $3.9 \mathrm{~mm}$ (one male was not measured because of badly damaged condition), 3 females CL $4.8-6.8 \mathrm{~mm}$ (BIOLAU, BL 10, Vaï-Lili site, 22 May 1989, slurp gun) [MNHN-Na 15264]; 1 male CL $4.6 \mathrm{~mm}, 1$ female CL $5.9 \mathrm{~mm}$ (same dive) [CBM-ZG 7976].

\section{Description}

Integument of body thin, but not membranous; surface shining, but inconspicuously pitted with shallow punctations and sparse short setae (Figure 2).

Rostrum (Figure 3A-C) short (0.27-0.40 times as long as carapace), directed forward, not reaching or reaching distal margin of basal segment of antennular peduncle, somewhat compressed laterally, styliform, terminating in sharp point; dorsal margin sharply edged, armed with 1-9 teeth (usually 5-7); ventrolateral margin sharply ridged, continuous with orbital margin; ventral margin flattened, unarmed. Carapace (Figures 2 \& 3A) somewhat compressed laterally, with very short, low, blunt postrostral median ridge extending to anterior 0.1 of $\mathrm{CL}$, remaining part of dorsal surface rounded; orbital margin evenly rounded; antennal spine well developed, directed forward in lateral view and slightly mesially in dorsal view; pterygostomian angle with sharp spine, but not reaching to level of tip of antennal spine; anterolateral margin between antennal spine and pterygostomian angle concave; posterodorsal submarginal groove shallow, rather inconspicuous.

Thoracic sternite with pair of slender submedian spines on seventh somite; median spur on eighth thoracic somite sharp.

Abdomen (Figures 2 \& 3D) rounded dorsally in all somites. Pleura of anterior two somites broadly rounded; pleuron of third somite with $2-8$ small teeth posterolateral to posteroventral margin; pleuron of fourth somite similarly armed with 4-8 small teeth; pleuron of fifth somite with 3-5 larger teeth on posterior margin. Sixth somite about 1.7 times as long as fifth somite, 1.1 times as long as high; posterolateral process short, terminating in acute tooth; posteroventral corner produced, terminating in acute or subacute tooth. First abdominal sternite with pair of very small, slender submedian spines, similar spines better developed and more strongly curved mesially on second and third sternites, again less developed spines on fourth sternite (all submedian spines greatly reduced in spawning females); fifth sternite with distinct median keel terminating posteriorly in acute spine; sixth sternite flattened, thin, transparent, with small pre-anal spine.

Telson (Figure 3E,F) 1.7-1.8 times as long as sixth abdominal somite, slightly narrowed posteriorly, width between posterolateral corners 0.7 of anterior width; dorsal surface nearly flat, bearing slightly sinuous dorsolateral row of 7-9 spines (excluding spines at posterolateral corner) on either side along posterior 0.8 length; posterior margin convex, bearing $12-19$ spines in total; $1-3$ spines at posterolateral corner shorter than mesial spines, simple, while remaining mesial spines elongate, bearing minute marginal setules.

Eye-stalks (Figure 3B,C) rather large but degenerated, broadly fused mesially without trace of median separation; cornea unfaceted, poorly organized retinal pigment discernible inside through cuticle; no distinct spine or tubercle on anterior surface of eye.

Antennular peduncle (Figure 3B,C) stout, slightly flattened dorsoventrally. Basal segment with distal width nearly half of its length; dorsal surface somewhat convex in distal part, but proximal part depressed, depression continuous with deep groove separating basal segment and stylocerite; distolateral tooth in lateral view, reaching 




Figure 2. Nautilocaris saintlaurentae gen. nov., sp. nov. Holotype female CL $7.3 \mathrm{~mm}$ from the North Fiji Basin (MNHN-Na 15261). Habitus, lateral view (fourth and fifth pereopods and second to fourth pleopods missing). Scale bar: $2 \mathrm{~mm}$. mid-length of penultimate segment, distomesial tooth much shorter than distolateral tooth, acute; stylocerite strong, tapering to slender point reaching or overreaching level of midlength of penultimate peduncular segment. Second segment with scattered short setae on dorsal surface; distomesial tooth as large as corresponding tooth on basal segment. Third segment slightly longer than wide. Flagella rather stout, unequal, inserted side by side on oblique terminal margin of distal segment; lateral flagellum shorter than mesial, aesthetasc-bearing portion occupying $0.8-0.9$ of total length of flagellum, articles each with tufts of aesthetascs on mesial face; mesial flagellum with annuli denser than those on lateral flagellum.

Antenna (Figure 3B,C) with basicerite stout, bearing blunt distal projection dorsolaterally and acute distal tooth ventrolaterally, exceeding former projection. Carpocerite (fifth segment of antennal peduncle) very stout, cylindrical, exceeding mid-length of scaphocerite. Antennal scale broadly oval with greatest width across level of midlength; lateral margin very slightly convex to sinuous, terminating in short, stout tooth separated by narrow incision and considerably exceeded by rounded blade; mesial margin noticeably convex; dorsal surface with distinct median ridge accompanied by deep groove. Flagellum stout, slightly longer than body, annuli dense.

Mandible (Figure 4A) with incisor process broad, somewhat tapering distally, bearing 6-8 unequal, acute or subacute teeth on mesial margin (distalmost tooth somewhat distant from remaining teeth); molar process slender, unarmed, not extending as far as incisor process; basal article of palp with deep notch on mesial surface proximal to midlength, distal article stout, slightly shorter than basal article, bearing numerous plumose setae of variable length.

Maxillule (Figure 4B) with coxal endite slightly tapering distomesially, with numerous setae on mesial margin; basial endite broad, mesial margin with two rows of small spines; ventral surface of basial endite with submarginal row of short setae adjacent to mesial margin; palp somewhat curved, slightly bilobed distally, bearing two setae; outer seta short, simple, arising subterminally from ventral surface slightly proximal to base of weakly produced outer lobule; inner seta plumose, arising from tip of inner lobule.

Maxilla (Figure 4G) with coxal endite composed of single lobe separated from basial endite by deep incision and following suture; basial endite consisting of two lobes, proximal lobe with roundly truncate mesial margin, distal lobe subtriangular, with submarginal row of setae on ventral surface; palp slender, weakly curved, reaching or slightly exceeding distal lobe of basal endite. Scaphognathite well expanded; anterior lobe subovate, with densely setose margin bearing longest setae along distomesial sector, but without facial setae; posterior lobe elongate, its mesial margin with row of very long setae becoming increasingly longer posteriorly.

First maxilliped (Figure 4D) with coxal endite somewhat thickened, with short setae on ventral surface and longer setae on mesial face; basial endite moderately broad, densely setose on ventral surface, mesial margin concave, fringed with dense setae; palp (not visible in ventral view) slender, weakly curved mesially, bearing 


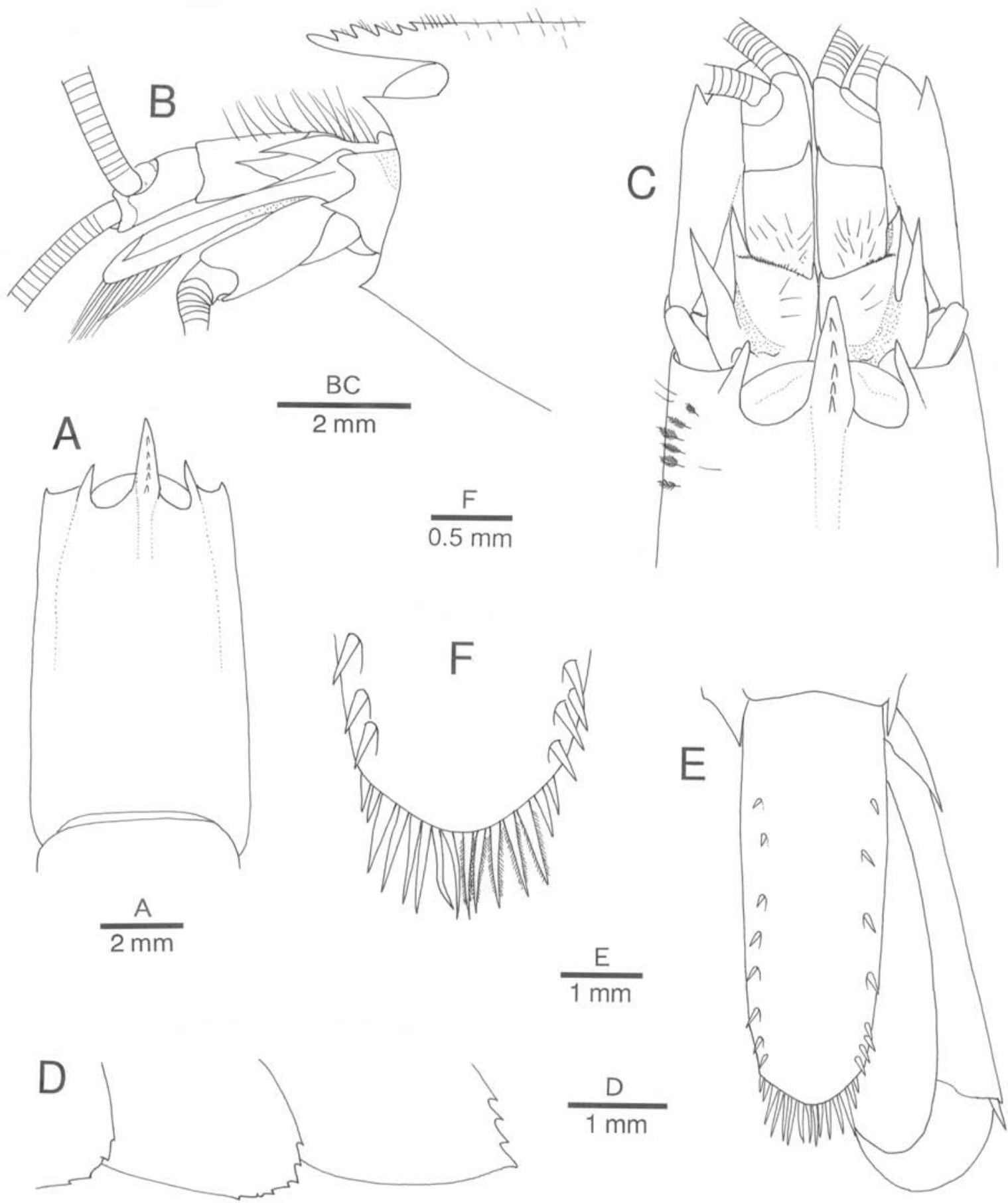

Figure 3. Nautilocaris saintlaurentae gen. nov., sp. nov. Holotype female GL $7.3 \mathrm{~mm}$ from the North Fiji Basin (MNHN-Na 15261): (A) carapace, dorsal view; (B) anterior part of carapace and cephalic appendages, lateral view; (C) same, dorsal view; (D) third to fifth abdominal pleura, lateral view (setae omitted); (E) telson, dorsal view (setae omitted); and (F) posterior margin of telson, dorsal view (setules on posterior spines partially omitted).

short apical bristles; exopod greatly expanded, broadly rounded and fringed with single or double row of long plumose setae, but without facial setae; exopodal flagellum absent; epipod large, foliacious, weakly bilobed.

Second maxilliped (Figure 4E) somewhat pediform, 6segmented (basis and ischium completely fused); coxa somewhat expanded mesially, with numerous setae on mesial face; basis-ischium fused segment longest and broadest, with fine row of setae on mesial margin; merus about half length of basis-ischium fused segment, with long setae on lateral face; carpus short, with long plumose setae on distal surface, proximomesial margin slightly produced on ventral side, partially covering basal part of propodus; propodus obliquely articulated to dactylus, with row of setae on mesial margin; dactylus longer than propodus, tapering to rounded tip, bearing numerous short setae on mesial to distal margins; exopod absent; epipod (Figure 4F) subovate, but often mutilated; rudiment of podobranch not reaching distal margin of basis-ischium fused segment, devoid of small papillae.

Third maxilliped (Figure 5A) 4-segmented, slightly overreaching anterior margin of scaphocerite. Coxa stout; 

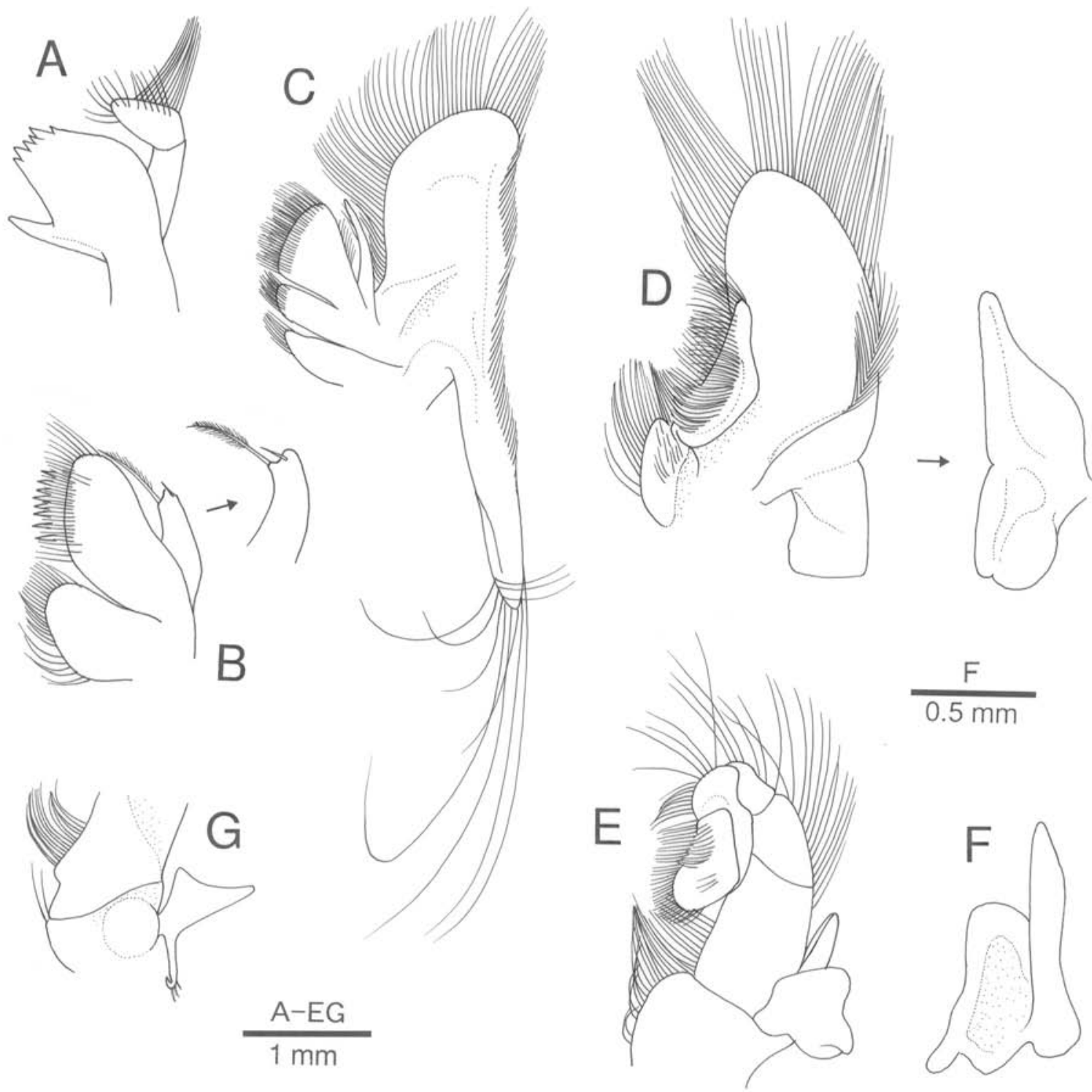

Figure 4. Nautilocaris saintlaurentae gen. nov., sp. nov. Holotype female GL $7.3 \mathrm{~mm}$ from the North Fiji Basin (MNHN-Na 15261). Left mouthparts: (A) mandible, ventral view; (B) maxillule, ventral view; inset, palp, lateral view; (C) maxilla, ventral view; (D) first maxilliped, ventral view; inset, epipod, dorsal view; (E) second maxilliped, ventral view; (F) epipod and podobranch of second maxilliped, dorsal view; and $(\mathrm{G})$ coxa of third maxilliped, ventral view.

epipod (Figure 4G) bi-lobed, with slender strap-like portion bearing terminal hook. Antepenultimate segment (basis-ischium-merus fused segment) somewhat flattened dorsoventrally, strongly sinuously curved in dorsal view, setose with slender spine at distolateral ventral corner, an assemblage of long setae on mesial face proximally. Distal two segments arched; penultimate segment (=carpus) with dense setae on mesial face; ultimate segment trigonal in cross section, gradually tapering distally and terminating in small corneous spine, with scattered long setae on lateral surface and obliquely transverse tracts of short stiff setae; 2-4 spinules adjacent to base of terminal spine.

First pereopod (Figure 5B) short, stout, slightly overreaching (when extended) anterior margin of scaphocerite at most, with chela and carpus oriented toward midline. Articulation between ischium and merus strongly oblique. Ischium and merus with scattered plumose setae on lateral and ventral surfaces. Merus somewhat compressed laterally and tapering distally, distal part of ventral surface slightly concave for reception of flexed carpus. Carpus shorter than merus, somewhat inflated, irregularly funnel-shaped, dorsal surface bent at right angle near tapered proximal end articulating with merus; distolateral margin slightly produced medially; distomesial margin more strongly produced, forming broadly triangular lobe; mesial face (Figure 5D) ventrally with shallow depression filled with numerous short setae and with one or two small movable spines proximal to depression; ventral crest oblique in lateral view, terminating in acute to blunt tooth. Palm (Figure 5C,D) short, strongly inflated, without patch of minute setae on mesial surface ventrally. Fingers curved and closing without hiatus; internal surfaces deeply concave; external surface of each finger convex; cutting edges uniformly offset, each armed with row of uniform, minute, erect, closely set teeth; cutting edge of fixed finger bordered with narrow, thin corneous 


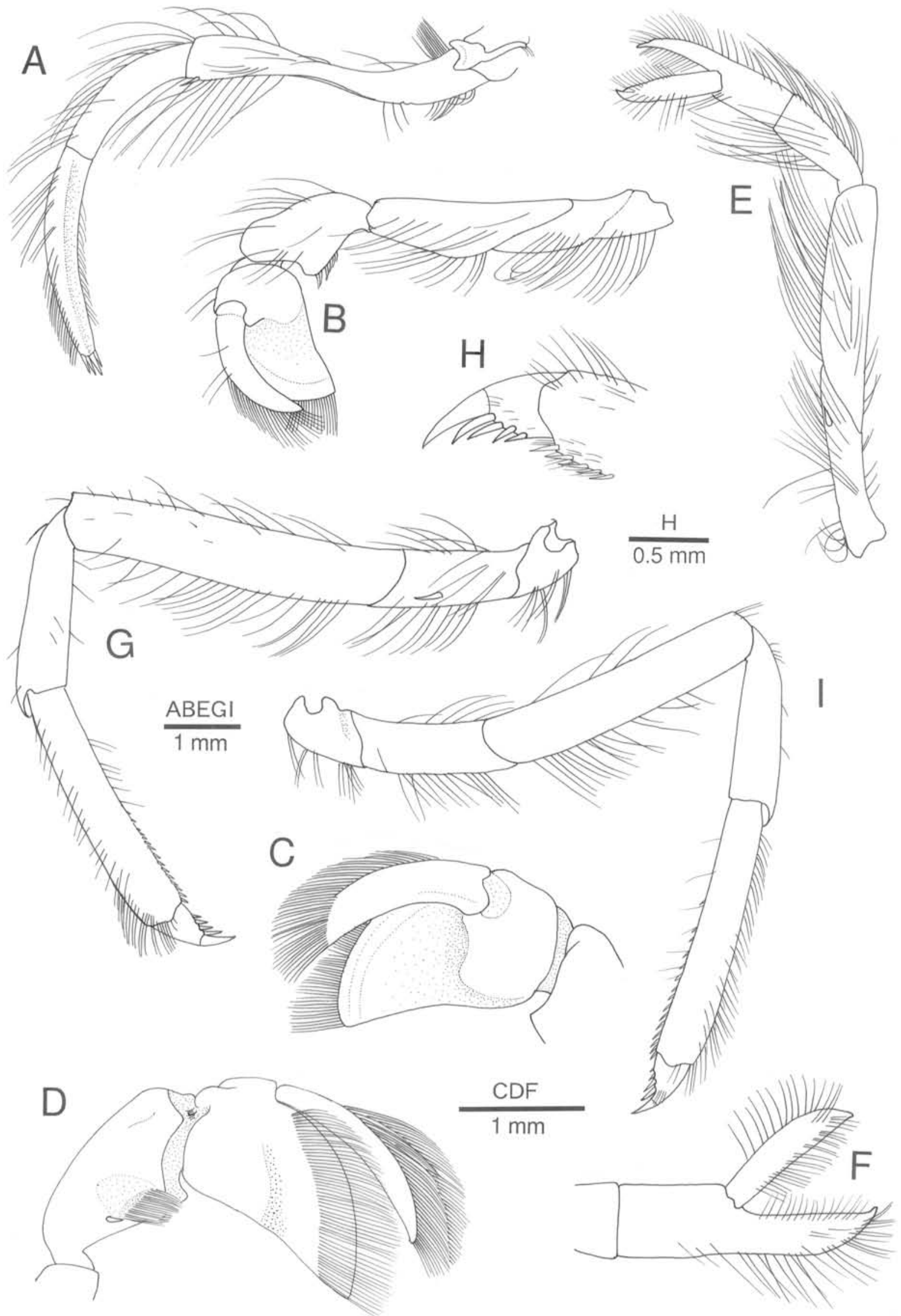

Figure 5. Nautilocaris saintlaurentae gen. nov., sp. nov. Holotype female CL $7.3 \mathrm{~mm}$ from the North Fiji Basin (MNHN-Na 15261). Pereopods (all left but right fourth pereopod): (A) third maxilliped, lateral view; (B) first pereopod, lateral view; (C) same, chela, lateral view; (D) same, chela and carpus, mesial view; (E) second pereopod, lateral view; (F) same, chela, outer view; (G) third pereopod, lateral view; $(\mathrm{H})$ same, dactylus, lateral view; and (I) fourth pereopod, lateral view. 

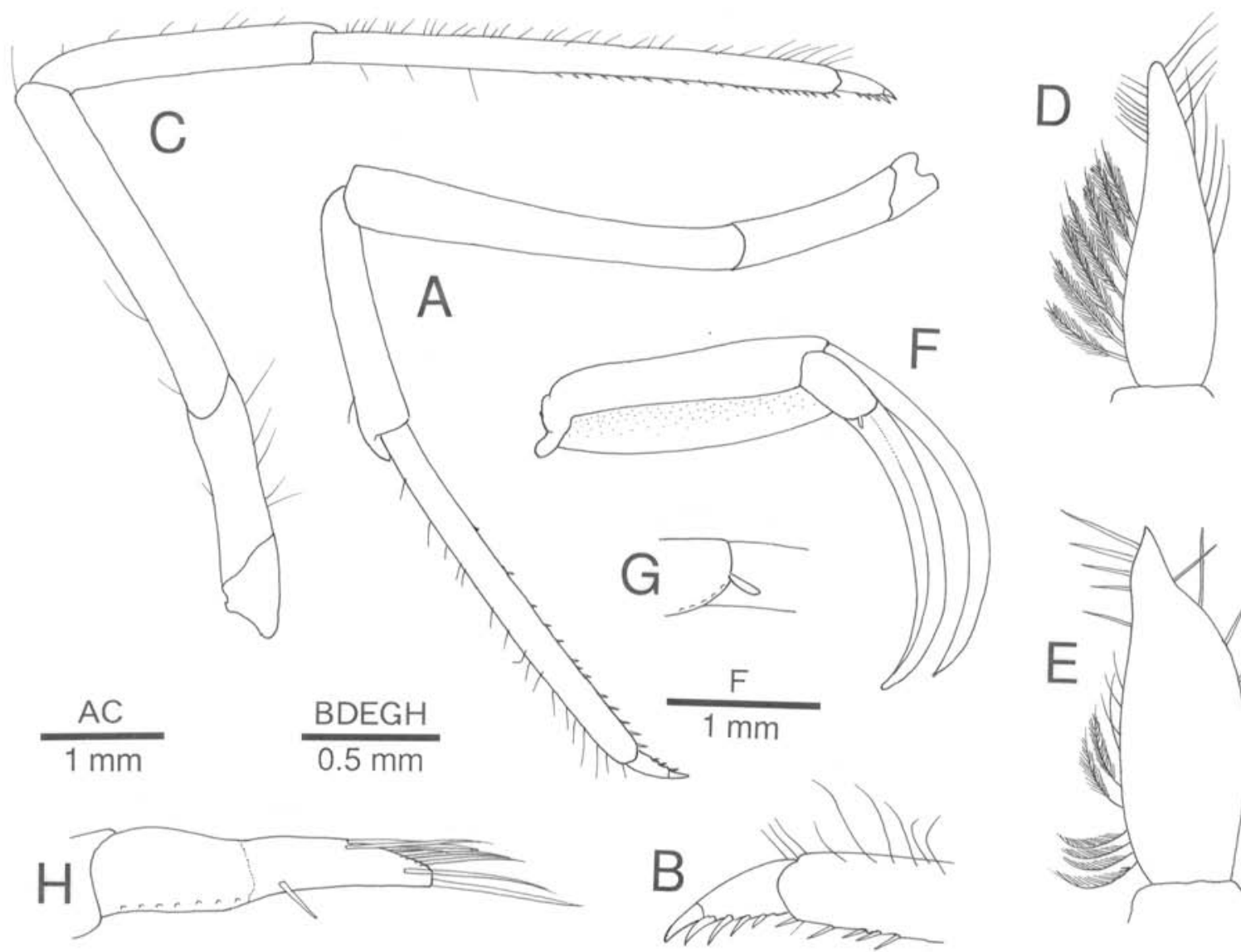

Figure 6. Nautilocaris saintlaurentae gen. nov., sp. nov. A-D, F, G, paratype female CL $6.3 \mathrm{~mm}$ from Lau Basin (MNHN-Na 15263); E, H, paratype male CL $4.8 \mathrm{~mm}$ from North Fiji Basin (MNHN-Na 15262): (A) left third pereopod, lateral view; (B) same, dactylus, lateral view; (C) right fifth pereopod, lateral view; (D), (E) endopod of left first pleopod, ventral view; (F) left second pleopod, mesial view; $(\mathrm{G})$ same, basal part, showing rudimentary appendix interna; and $(\mathrm{H})$ left appendix masculina and appendix interna, mesial view.

plate including tip; internal surface with submarginal row of sparse short setae along cutting edge; external surface of fixed finger with submarginal rows of numerous long setae. Dactylus 2.0-2.8 times longer than palm, uniformly narrowed distally, considerably flattened in distal $0.5-0.8$; internal surface with submarginal row of short, sparse setae along cutting edge; external surface with submarginal row of long setae along cutting edge in at least distal half.

Second pereopod (Figure 5E) slightly more slender than other pereopods, reaching distal margin of scaphocerite at most. Articulation between ischium and merus strongly oblique. Ischium unarmed or armed with one movable spine strongly pressed on lateral surface. Merus 5.1-5.3 times as long as maximum height, occasionally with long setae, setae also present on ischium on ventral surface. Carpus occasionally with long setae on dorsal and lateral surfaces. Chela (Figure 5F) 1.2-1.3 times as long as carpus, slightly broadened distally, 3.30-3.70 times longer than greatest width; fingers longer than palm, each terminating in small corneous spine, crossing at tip; external surfaces of fingers slightly depressed toward cutting edges, with short to long setae; cutting edges each with row of minute corneous spinules at least in distal half.
Third to fifth pereopods (Figures 5G,I \& 6A,C) similar in structure, but increasing in length from anterior pair to posterior pair, very variable in stoutness (cf. Figure 5G and Figure 6A). Third pereopod (Figures 5G \& 6A) at most overreaching distal margin of scaphocerite by length of dactylus and full length of propodus, somewhat compressed laterally; ischium with one or two spines on lateral surface ventrally; merus $4.5-6.5$ times as long as high, occasionally with long plumose setae on dorsal and ventral surfaces; carpus-propodus combined slightly shorter than merus-ischium combined; carpus $0.7-0.8$ times as long as propodus; propodus 5.6-11.9 times as long as high, with two rows of spinules on ventral surface; dactylus (Figures $5 \mathrm{H} \& 6 \mathrm{~B}$ ) stout, $0.2-0.3$ times as long as propodus, unguis rather clearly demarcated, sometimes elongate, ventral margin with single row of 3-5 accessory spinules increasing in size distally. Fourth pereopod (Figure 5I) at most overreaching distal margin of scaphocerite by length of dactylus and half of propodus; ischium unarmed or with one spine; carpus-propodus combined subequal in length to merus-ischium combined. Fifth pereopod (Figure 6C) at most overreaching distal margin of scaphocerite by length of dactylus and half of propodus; ischium unarmed; carpus-propodus combined longer than merus-ischium combined; ventral surface of 
Table 1. Nautilocaris saintlaurentae gen. nov., sp. nov. Branchial formula; epipods and corresponding setobranchs, as well as exopods, are also indicated (r: rudimentary).

\begin{tabular}{|c|c|c|c|c|c|c|c|c|}
\hline \multirow[b]{3}{*}{ Thoracic somites } & 1 & 2 & 3 & 4 & 5 & 6 & 7 & 8 \\
\hline & \multicolumn{4}{|c|}{ Maxillipeds } & \multicolumn{4}{|c|}{ Pereopods } \\
\hline & 1 & 2 & 3 & 1 & 2 & 3 & 4 & 5 \\
\hline Pleurobranchs & - & - & - & + & + & + & + & + \\
\hline Arthrobranchs & - & - & 1 & 1 & 1 & 1 & 1 & - \\
\hline Podobranchs & - & $r$ & - & - & - & - & - & - \\
\hline Epipods & + & + & + & + & + & + & + & - \\
\hline Setobranchs & - & - & - & + & + & + & + & + \\
\hline Exopods & + & - & - & - & - & - & - & - \\
\hline
\end{tabular}

propodus with double or triple row of setulose spinules on lateral side and single row of simple spinules on mesial side.

Branchial formula summarized in Table 1. Pleurobranchs on fourth to eighth thoracic somites asymmetrically Y-branched, noticeably increasing in length posteriorly, apices directed forward. Arthrobranchs on third to seventh thoracic somites moderately developed, nearly symmetrically U-branched, but last one on seventh somite distinctly smaller than preceding ones. Epipods on first to fourth pereopods strap-like, similar in shape to that on third maxilliped. Setobranchs on fourth to eighth thoracic somites corresponding to epipods on third maxilliped to fourth pereopods.

Endopod of first pleopod in males (Figure 6E) with row of sparse plumose setae on both margins, terminating distomesially in subtriangular lobe bearing one distal and two or three subdistal bristles, all bristles essentially directed to midline of body; that of female (Figure 6D) uniformly tapering with margins fringed sparsely with plumose setae.

Second to fourth pleopods bearing greatly reduced or rudimentary appendix interna (Figure 6F,G,H); fifth pleopod bearing normally developed appendix interna bearing terminal cluster of cincinnuri. Appendix masculina on male second pleopod (Figure 6H) exceeding midlength of endopod, bearing eight to ten long bristles distally.

Uropod (Figure 3E) with both rami elongate oval, exceeding posterior margin of telson; endopod shorter and narrower than exopod; exopod with straight lateral margin terminating in tiny acuminate distolateral tooth; long movable spine arising just mesial to distolateral tooth; suture distinct, sinuous.

\section{Colour in life}

Generally whitish, without markings.

\section{Size}

Males CL 4.1-5.6 mm; females CL 5.1-7.8 mm. Maximum TL $35 \mathrm{~mm}$.

\section{Variation}

This new species exhibits a great variation in the shape of the third to fifth pereopods as in the close relative Mirocaris fortunata. Two extreme examples showing the variation of the stoutness of the third pereopod are given (Figures 5G \& 6A). Setation of the thoracic appendages is also variable in $\mathcal{N}$. saintlaurentae.

\section{Etymology}

This new species is named after the late Michèle de Saint Laurent for her generous offerings, important findings and valuable opinions on the family Alvinocarididae.

Ecology

The White Lady site (North Fiji Basin) consists of chimneys of anhydrite from one to three metres height, emitting vigorous transparent hydrothermal fluids at $296^{\circ} \mathrm{C}$. At the Vaï-Lili site (Lau Basin), there are tall black and white smokers venting fluids up to $400^{\circ} \mathrm{C}$. The chemical composition of the fluids of these two sites is similar to the other hydrothermal systems (see Ishibashi et al., 1994), except for a very low $\mathrm{pH}(\mathrm{pH} 2)$ and a strong content of metallic ions (predominantly $\mathrm{As}$ and $\mathrm{Pb}$ ) at Vaï-Lili, and for a marked depletion in Mn and Fe at White Lady (Fouquet et al., 1993).

Animal communities associated with hydrothermal discharges are generally located around the chimneys, where fluids are percolating at temperatures between 5 and $33^{\circ} \mathrm{C}$; water temperature remote from the chimneys has been measured at $1.7^{\circ} \mathrm{C}$ (Desbruyères et al., 1994). The White Lady and Vaï-Lili sites are characterized by a predominance of two gastropod species as primary consumers, Alvinoconcha hessleri Okutani \& Ohta, 1988 and Ifremeria nautilei Bouchet \& Warén, 1991. Dense beds of a bivalve, Bathymodiolus sp., the sessile barnacle Neoverruca brachylepadoformis Newman \& Yamaguchi, 1995 and pogonophoran and alvinellid tube-worms, also occur. Reptant decapod crustaceans are diverse, represented by the bythograeid crab Austinograea alaysae Guinot, 1990, the galatheoid lobsters Munidopsis lauensis Baba \& de Saint Laurent, 1992, M. starmer Baba \& de Saint Laurent, 1992, Munida magniantennatulata Baba \& Türkay, 1992, Uroptychus bicavus Baba \& de Saint Laurent, 1992, U. thermalis Baba \& de Saint Laurent, 1992 and the lithodid crab Paralomis hirtella de Saint Laurent \& Macpherson, 1997 (Guinot, 1990; Baba \& de Saint Laurent, 1992; Baba \& Türkay, 1992; de Saint Laurent \& Macpherson, 1997).

The videos showed abundant shrimps of a mixture of more than one species, crawling or resting on the gastropod and bivalve clumps, or on the naked substratum (basalt or anhydrite deposits). The density of shrimps was about 80 individuals $\mathrm{m}^{2}$. The collection by the submersible 'Nautile' revealed that four shrimp species inhabited the explored sites, $\mathcal{N}$. saintlaurentae gen. nov., sp. nov., Chorocaris vandoverae, Alvinocaris sp., and Lebbeus sp. aff. washingtonianus. The most abundant was Chorocaris vandoverae, recognizable by its greater size and small, unarmed rostrum. Alvinocaris sp. was recognizable by its well-developed rostrum and the red colour of the cephalothorax. The present new species was seldom seen in the video records. The diet of $\mathcal{N}$. saintlaurentae has not been investigated. Nevertheless, the similarity of its mouthpart and chela morphology to those of other alvinocaridids suggests that the new species ingests free bacteria, mollusc pseudofaeces or other detritus, as do most other species of the family (Segonzac et al., 1993). 
The authors thank the chief scientists and the crew of RV 'Nadir' and submersible 'Nautile' for collecting specimens and making them available for study: A.-M. Alayse (Ifremer) of BIOLAU Cruise; and D. Desbruyères (Ifremer) and S. Ohta (Ocean Research Institute, University of Tokyo) of STARMER II. We also thank V. Martin (Ifremer) for preparing Figure 1 (map) and three anonymous referees for improving the manuscript.

\section{REFERENCES}

Baba, K. \& Saint Laurent, M. de, 1992. Chirostylid and Galatheid crustaceans (Decapoda: Anomura) from active thermal vent areas in the southwest Pacific. Scientia Marina, 56, 321-332.

Baba, K. \& Türkay, M., 1992. Munida magniantennulata, a new deep-sea decapod crustacean from active thermal vent areas of Valu-Fa-Ridge in the Lau Basin, SW-Pacific. Senckenbergiana Maritima, 22, 203-210.

Calman, W.T., 1896. On deep-sea Crustacea from the south west of Ireland. Transactions of the Royal Irish Academy, 31, 1-20.

Christoffersen, M.L., 1986. Phylogenetic relationships between Oplophoridae, Atyidae, Pasiphaeidae, Alvinocarididae fam. n., Bresiliidae, Psalidopodidae and Disciadidae (Crustacea, Caridea, Atyoidea). Boletim de Zoologia, Universidade de São Paulo, 10, 273-281.

Desbruyères, D., Alayse-Danet, A.-M., Ohta, S. \& the Scientific Parties of Biolau \& Starmer cruises, 1994. Deep-sea hydrothermal communities in southern Pacific back-arc basins (the North Fiji and Lau Basins): Composition, microdistribution and food-web. Marine Geology, 116, 227-242.

Fouquet, Y., Stackelberg, U. von, Charlou, J.-L., Erzinger, J., Herzig, P.-M., Muhe, R. \& Wiedicke, M., 1993. Metallogenesis in back-arc environments: the Lau Basin example. Economic Geology, 88, 2154-2181.

Guinot, D., 1990. Austinograea alayseae sp. nov., crabe hydrothermal découvert dans le bassin de Lau, Pacifique sudoccidental (Crustacea Decapoda Brachyura). Bulletin du Muséum National d'Histoire Naturelle, Série 4e, 12, 879-903.

Holthuis, L.B., 1993. The recent genera of the caridean and stenopodidean shrimps (Crustacea, Decapoda) with an appendix on the order Amphionidacea. Leiden: Nationaal Natuurhistorisch Museum.

Ishibashi, J., Grimaud, D., Nojiri, Y., Auzende, J.-M. \& Urabe, T., 1994. Fluctuation of chemical compositions of the phaseseparated hydrothermal fluid from the North Fiji Basin Ridge. Marine Geology, 116, 215-226.

Komai, T. \& Segonzac, M., 2003. A review of the hydrothermal vent shrimp genus Mirocaris, redescription of $M$. fortunata and reassessment of the taxonomic status of the family Alvinocarididae (Crustacea: Decapoda: Caridea). Cahiers de Biologie Marine, 44, 199-215.

Komai, T. \& Segonzac, M., in press. A revision of the genus Alvinocaris Williams and Chace (Crustacea: Decapoda: Caridea: Alvinocarididae), with descriptions of a new genus and a new species of Alvinocaris. Fournal of Natural History.

Martin, J.W. \& Christiansen, J.C., 1995. A new species of the shrimp genus Chorocaris Martin \& Hessler, 1990 (Crustacea: Decapoda: Bresiliidae) from hydrothermal vent fields along Mid-Atlantic Ridge. Proceedings of the Biological Society of Washington, 108, 220-227.
Martin, J.W. \& Hessler, R.R., 1990. Chorocaris vandoverae, a new genus and species of hydrothermal vent shrimp (Crustacea: Decapoda: Bresiliidae) from the western Pacific. Contributions in Science, 417, 1-11.

Newman, W.A. \& Yamaguchi, T., 1995. A new sessile barnacle (Cirripedia, Brachylepadomorpha) from the Lau Back-Arc Basin, Tonga; first record of a living representative since the Miocene. Bulletin du Muséum National d'Histoire Naturelle, Paris, Série 4, A, 17, 221-243.

Okutani, T. \& Ohta, S., 1998. A new gastropod mollusk associated with hydrothermal vents in the Mariana Back-Arc Basin, western Pacific. Venus, 47, 1-9.

Rathbun, M.J., 1902. Descriptions of new decapod crustaceans from the west coast of North America. Proceedings of the United States National Museum, 24, 885-905.

Saint Laurent, M. de \& Macpherson, E., 1997. Une nouvelle espèce du genre Paralomis White, 1856, des sources hydrothermales du Sud-Ouest Pacifique (Crustacea, Decapoda, Lithodidae). Zoosystema, 19, 721-727.

Segonzac, M., Saint Laurent, M. de \& Casanova, B., 1993. L'énigme du comportement trophique des crevettes Alvinocarididae des sites hydrothermaux de la dorsale médioatlantique. Cahiers de Biologie Marine, 34, 535-571.

Shank, T.M., Black, M.B., Halanych, K.M., Lutz, R.A. \& Vrijenhoek, R.C., 1999. Miocene radiation of deep-sea hydrothermal vent shrimp (Caridea: Bresiliidae): evidence from mitochondrial cytochrome oxydase subunit I. Molecular Phylogenetics and Evolution, 13, 244-254.

Vereshchaka, A.L., 1997. A new family for a deep-sea caridean shrimp from North Atlantic hydrothermal vents. Fournal of the Marine Biological Association of the United Kingdom, 77, 425-438.

Watabe, H. \& Hashimoto, J., 2002. A new species of the genus Rimicaris (Alvinocarididae: Caridea: Decapoda) from the active hydrothermal vent field "Kairei Field", on the Central Indian Ridge, the Indian Ocean. Zoological Science, 19, 1167-1174.

Webber, W.R., 2004. A new species of Alvinocaris (Crustacea: Decapoda: Alvinocarididae) and new records of alvinocaridids from hydrothermal vents north of New Zealand. Zootaxa, 444, 1-26.

Williams, A.B., 1988. New marine decapod crustaceans from waters influenced by hydrothermal discharge, brine, and hydrocarbon seepage. Fishery Bulletin, 86, 263-287.

Williams, A.B. \& Chace, F.A. Jr, 1982. A new caridean shrimp of the family Bresiliidae from thermal vents of the Galapagos Rift. Fournal of Crustacean Biology, 2, 136-147.

Williams, A.B. \& Dobbs, F.C., 1995. A new genus and species of caridean shrimp (Crustacea: Decapoda: Bresiliidae) from hydrothermal vents on Loihi Seamount, Hawaii. Proceedings of the Biological Society of Washington, 108, 228-237.

Williams, A.B. \& Rona, P., 1986. Two new caridean shrimps (Bresiliidae) from a hydrothermal vent on the Mid-Atlantic Ridge. Fournal of Crustacean Biology, 6, 446-462. 